\title{
Prone positioning combined with high-flow nasal or conventional oxygen therapy in severe Covid-19 patients
}

\author{
Cyrielle Despres ${ }^{1}$, Yannick Brunin ${ }^{1}$, Francis Berthier ${ }^{1}$, Sebastien Pili-Floury ${ }^{1,2}$ and Guillaume Besch ${ }^{1,2^{*}}$ (D)
}

\section{Dear Editor,}

A massive outbreak of coronavirus disease 2019 (Covid-19) occurred in France in March and April 2020. About 20\% of Covid-19 patients develop acute respiratory distress syndrome (ARDS), with mortality ranging from 20 to $50 \%$. Since the publication of the PROSEVA study [1], prone positioning (PP) has become a cornerstone of management of mechanically ventilated severe ARDS patients.

Recently, PP was reported to enhance oxygenation when combined with high-flow nasal cannula in severe non-Covid-19 ARDS [2,3] and to improve lung recruitability when combined with non-invasive ventilation in severe Covid-19 ARDS [4].

We report the case of 6 severe Covid-19 patients admitted to our critical care unit between March and April 2020, who had PP combined with either highflow nasal oxygen (HFNO) or conventional oxygen therapy (COT). All patients had laboratory-confirmed SARS-CoV-2 infection, defined as a positive result of real-time reverse transcriptase-polymerase chain reaction (RT-PCT) from nasal and pharyngeal swabs. ARDS was defined according to the Berlin definition, with a ratio of $\mathrm{P}_{\mathrm{a}} \mathrm{O}_{2}$ to $\mathrm{F}_{\mathrm{i}} \mathrm{O}_{2}\left(\mathrm{P}_{\mathrm{a}} \mathrm{O}_{2} / \mathrm{F}_{\mathrm{i}} \mathrm{O}_{2}\right) \leq 300 \mathrm{mmHg}$. All patients presented rapid worsening of dyspnea and oxygenation, defined as $\mathrm{S}_{\mathrm{p}} \mathrm{O}_{2} \leq 92 \%$ despite increasing oxygen supply to more than $\geq 5 \mathrm{~L} / \mathrm{min}$. All patients were spontaneously ventilated, and no patient had criteria that indicated the need for emergency intubation. All patients had predominant posterior lung

\footnotetext{
* Correspondence: gbesch@chu-besancon.fr

'Department of Anesthesiology and Intensive Care Medicine, University Hospital of Besancon, University of Franche-Comte, Besancon, France ${ }^{2}$ EA 3920, University of Franche-Comte, 3 bvd Alexander Fleming, 25000 Besancon, France
}

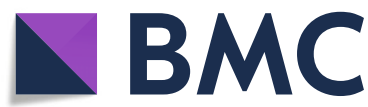

condensation documented either on lung ultrasound or CT-scan.

HFNO or COT was prescribed to reach $\mathrm{S}_{\mathrm{p}} \mathrm{O}_{2} \geq 94 \%$. The clinical course of ARDS was closely followed using the ROX index [5]. PP was proposed to patients who presented clinical worsening, as persistent hypoxia despite increasing oxygen delivery, or a decrease in the ROX index. PP was maintained depending on patient clinical tolerance and could be repeated if necessary.

Relevant clinical, laboratory data and HFNO or COT settings were obtained from medical records and are presented in Table 1.

A total of 9 PP sessions was performed in 6 patients. $\mathrm{PP}$ was combined with HFNO in 4 sessions and to COT in 5 sessions. The $\mathrm{P}_{\mathrm{a}} \mathrm{O}_{2} / \mathrm{F}_{\mathrm{i}} \mathrm{O}_{2}$ ratio improved after 4 sessions, including 3 sessions combined with HFNO and 1 session combined with COT. Intubation was avoided in 3 patients.

This is the first report of PP combined with either HFNO or COT in severe Covid-19 pneumonia. The proportion of patients with $\mathrm{P}_{\mathrm{a}} \mathrm{O}_{2} / \mathrm{F}_{\mathrm{i}} \mathrm{O}_{2}$ ratio improvement after PP appeared to be higher with HFNO compared to conventional oxygen therapy, suggesting the need for a high flow of oxygen to provide a significant oxygen response [6]. All patients described subjective enhancement of dyspnea after prone positioning, but this data was not quantified. The efficacy of PP combined with HFNO therapy or non-invasive ventilation was recently reported in small cohorts of non-infectious and infectious non-Covid-19 ARDS patients [2, 3]. Interestingly, the proportion of patients with an improvement in $\mathrm{P}_{\mathrm{a}} \mathrm{O}_{2} / \mathrm{F}_{\mathrm{i}} \mathrm{O}_{2}$ ratio and the rate of intubation avoided in these 2 studies were very 
Table 1 Clinical characteristics and outcomes of patients

\begin{tabular}{|c|c|c|c|c|c|c|c|c|c|}
\hline $\begin{array}{l}\text { Case } \\
\text { no. }\end{array}$ & Gender & $\begin{array}{l}\text { Age } \\
\text { (years) }\end{array}$ & $\begin{array}{l}\text { SAPS } \| \text { score at } \\
\text { admission }\end{array}$ & $\begin{array}{l}\text { Ventilatory } \\
\text { support }\end{array}$ & $\begin{array}{l}\text { BMl } \\
\left(\mathrm{kg} \cdot \mathrm{m}^{-2}\right)\end{array}$ & $\begin{array}{l}\text { Duration of prone } \\
\text { positioning (hours) }\end{array}$ & $\begin{array}{l}\mathrm{P}_{\mathrm{a}} \mathrm{O}_{2} / \mathrm{F}_{\mathrm{i}} \mathrm{O}_{2} \text { before } \\
\text { prone position }\end{array}$ & $\begin{array}{l}\mathrm{P}_{\mathrm{a}} \mathrm{O}_{2} / \mathrm{F}_{\mathrm{i}} \mathrm{O}_{2} \text { after } \\
\text { prone position }\end{array}$ & Intubation \\
\hline 1 & Male & 60 & 27 & HFNO $50 \mathrm{~L} / \mathrm{min}$ & 27 & 7 & 144 & 254 & Yes \\
\hline \multirow[t]{2}{*}{2} & Male & 54 & 32 & COT $6 \mathrm{~L} / \mathrm{min}$ & 27 & 1 & 215 & 147 & No \\
\hline & & & & HFNO $50 \mathrm{~L} / \mathrm{min}$ & & 1 & 129 & 156 & \\
\hline \multirow[t]{2}{*}{3} & Male & 55 & 26 & HFNO $50 \mathrm{~L} / \mathrm{min}$ & 26 & 16 & 126 & 194 & No \\
\hline & & & & HFNO $50 \mathrm{~L} / \mathrm{min}$ & & 16 & 183 & 162 & \\
\hline 4 & Male & 66 & 37 & COT $5 \mathrm{~L} / \mathrm{min}$ & 31 & 4 & 150 & 242 & Yes \\
\hline \multirow[t]{2}{*}{5} & Male & 61 & 28 & COT $3 \mathrm{~L} / \mathrm{min}$ & 21 & 1 & 274 & 225 & Yes \\
\hline & & & & COT $3 \mathrm{~L} / \mathrm{min}$ & & 2 & 193 & 124 & \\
\hline 6 & Male & 64 & 36 & COT $5 \mathrm{~L} / \mathrm{min}$ & 27 & 2 & 212 & 168 & $\mathrm{No}$ \\
\hline
\end{tabular}

$\mathrm{F}_{\mathrm{i}} \mathrm{O}_{2}$ with COT was calculated using the following formula: $\mathrm{F}_{\mathrm{i}} \mathrm{O}_{2}=21+\left(4 \times\right.$ oxygen flow rate in $\left.\mathrm{L} \mathrm{min}^{-1}\right)$

$B M I$ body mass index, HFNO high-flow nasal oxygen, COT conventional oxygen therapy

close to that observed in the present series of 6 severe Covid-19 patients.

Considering these observations, PP combined with either HFNO or COT could be proposed in spontaneously breathing, severe Covid-19 patients to avoid intubation. The indication for PP in non-intubated Covid-19 pneumonia needs to be addressed in further studies.

\section{Acknowledgements}

The authors thank Fiona Ecarnot, Ph.D., University Hospital of Besancon and University of Franche-Comte, Besancon, France, for her assistance in preparing the manuscript.

\section{Authors' contributions}

Cyrielle Despres, Yannick Brunin, Francis Berthier, Sebastien Pili-Floury, and Guillaume Besch had substantial contributions to conception and design of the study, acquisition and interpretation of data, and drafting of the article manuscript. The author(s) read and approved the final manuscript.

\section{Funding}

No funding to report.

\section{Availability of data and materials}

Not applicable.

\section{Ethics approval and consent to participate}

Not applicable.

\section{Consent for publication}

Not applicable.

\section{Competing interests}

The authors have no conflict of interest to disclose.

Received: 12 May 2020 Accepted: 18 May 2020

Published online: 26 May 2020

\section{References}

1. Guérin C, Reignier J, Richard J-C, Beuret P, Gacouin A, Boulain T, et al. Prone positioning in severe acute respiratory distress syndrome. N Engl I Med. 2013;368:2159-68.

2. Ding L, Wang L, Ma W, He H. Efficacy and safety of early prone positioning combined with HFNC or NIV in moderate to severe ARDS: a multi-center prospective cohort study. Crit Care. 2020;24:28.

3. Pérez-Nieto OR, Guerrero-Gutiérrez MA, Deloya-Tomas E, Ñamendys-Silva SA. Prone positioning combined with high-flow nasal cannula in severe noninfectious ARDS. Crit Care. 2020;24:114.
4. Pan C, Chen L, Lu C, Zhang W, Xia J-A, Sklar MC, et al. Lung recruitability in SARS-CoV-2 associated acute respiratory distress syndrome: a single-center, observational study. Am J Respir Crit Care Med. 2020;201(10):1294-297.

5. Roca O, Caralt B, Messika J, Samper M, Sztrymf B, Hernández G, et al. An index combining respiratory rate and oxygenation to predict outcome of nasal high-flow therapy. Am J Respir Crit Care Med. 2019;199:1368-76.

6. Scaramuzzo G, Ball L, Pino F, Ricci L, Larsson A, Guérin C, et al. Influence of positive end-expiratory pressure titration on the effects of pronation in acute respiratory distress syndrome: a comprehensive experimental study. Front Physiol. 2020;11:179.

\section{Publisher's Note}

Springer Nature remains neutral with regard to jurisdictional claims in published maps and institutional affiliations.

Ready to submit your research? Choose BMC and benefit from:

- fast, convenient online submission

- thorough peer review by experienced researchers in your field

- rapid publication on acceptance

- support for research data, including large and complex data types

- gold Open Access which fosters wider collaboration and increased citations

- maximum visibility for your research: over $100 \mathrm{M}$ website views per year

At BMC, research is always in progress.

Learn more biomedcentral.com/submissions 